\title{
Aglepristone efficiency with and without the canine pyometra cloprostenol
}

\section{Eficacia del aglepristone con y sin cloprostenol en el tratamiento del piómetra canino}

\author{
Víctor Molina D, ${ }^{1 *}$ M.Sc.
}

${ }^{1}$ CAEQUINOS-Unisabaneta. Grupo de investigación RICERCA, Calle 75 Sur N 34-120, Sabaneta, Colombia. *Correspondencia: dooncanmc@hotmail.com

Received: August 2014; Accepted: February 2015.

\begin{abstract}
Objective. Evaluate the effectiveness of aglepristone with and without cloprostenol for treating canine pyometra. Materials and methods. Ten female French Bulldogs between 3-8 years of age diagnosed with pyometra were divided into two groups, one receiving a $10 \mathrm{mg} / \mathrm{kg}$ dose of aglepristone subcutaneously on days $1,2,8,14$ and 28 , and the other an equal dose on days $1,3,8$ and 15 , as well as a $1 \mu \mathrm{g} / \mathrm{kg}$ dose of cloprostenol subcutaneously on days 3 and 8 . Both groups received $5 \mathrm{mg} / \mathrm{kg}$ of enrofloxacin orally every 12 hours for 28 days. Hematic profiles were generated on days 1 and 28 and counted days until the next heat, expelling purulent material and of clinical recuperation. Results. There was no statistical difference in the variables of the line red blood cells between times and protocols. The line of white blood cells showed a statistical difference between days of treatment but not between the two groups. Both treatments were effective resulting in complete clinical recuperation. The combination of aglepristone with cloprostenol acted more quickly, decreasing the number of days of secretion, abdominal pain, and the recuperation of normal activity and appetite. All 10 females were bred during their first heat. Three females from the aglepristone group and one from the combined aglepristone with cloprostenol group were impregnated. Conclusions. Both protocols, combined with enrofloxacin, produced complete clinical recuperation in bitches with pyometra, but it was achieved more rapidly when given the combination of both aglepristone and cloprostenol.
\end{abstract}

Key words: Antiprogestins, estrogens, endometrial hyperplasia, bitch, progesterone, prostaglandin (Source: $\mathrm{MeSH}$ ).

\section{RESUMEN}

Objetivo. Evaluar la efectividad del aglepristone con y sin el cloprostenol en el tratamiento del piómetra canino. Materiales y métodos. Diez hembras Bulldog Francés entre 3-8 años de edad con diagnóstico de piómetra, se dividieron en dos grupos, uno recibió aglepristone a la dosis de $10 \mathrm{mg} / \mathrm{kg}$ subcutáneo los días $1,2,8,14$ y 28 , y otro una dosis igual los días $1,3,8$ y 15, más cloprostenol a dosis de $1 \mu \mathrm{g} / \mathrm{kg}$ subcutáneo los días 3 y 8 . Ambos grupos recibieron enrofloxacina $5 \mathrm{mg} / \mathrm{kg}$ oral cada 12 horas por 28 días. Se realizaron perfiles hemáticos los días 1 y 28 , y se valoraron días de retorno al celo, expulsión del material purulento y de recuperación clínica. Resultados. No hubo diferencia estadística en las variables de la línea roja sanguínea entre tiempos y protocolos. La línea de glóbulos blancos mostró diferencia estadística entre los días de tratamiento pero no entre los dos grupos. Ambos tratamientos fueron eficaces en la 
recuperación clínica completa, siendo el aglepristone más cloprostenol más rápido en disminuir los días de secreción, dolor abdominal, recuperación de la actividad normal y apetito. Las 10 hembras fueron servidas en el primer celo y quedaron preñadas tres hembras del grupo del aglepristone y una del grupo aglepristone con cloprostenol respectivamente. Conclusiones. Ambos protocolos combinados con enrofloxacina, produjeron la recuperación clínica completa en perras con piómetra, pero se consiguió más rápidamente en el grupo de aglepristone con cloprostenol.

Palabras clave: Antiprogestágenos, estrógenos, hiperplasia endometrial, perra, progesterona, prostaglandina (Fuente: MeSH).

\section{INTROODUCTION}

Pyometra is a uterine pathology of bacterial origin stimulated by progesterone during consecutive heat cycles, and by an exogenous estrogen and/ or progesterone treatment (1). It is reported principally in females over six years of age $(2,3)$.

It is a pathological process that usually begins with cystic endometrial hyperplasia (CEH), and that permits the proliferation of vaginal bacteria, accumulating purulent material inside the uterus (3-5). It is considered one of the most frequent pathological alterations in canine reproduction $(4,6)$. It begins during the estrous phase of the reproductive cycle, by morphological changes induced by progesterone (P4) and estrogen (E2), along with an abnormal response in the uterus during the luteal phase, which combined with bacterial action results in pyometra $(5,7)$. Two clinical forms are distinguished: closed pyometra, whose signs are very severe and open pyometra. Some of the common signs are: vomiting, polydipsia, polyuria and anorexia $(2,3,5)$.

Treatment of pyometra should be urgent and aggressive, including the extraction of contents, which is generally surgical in $80 \%$ of cases (8$10)$. None the less, pharmacological treatment is also possible (11-13). The effectiveness of the use of natural prostaglandin $\mathrm{F} 2 \alpha$ has been traced in $55 \%$ of cases of open pyometra and $24 \%$ of closed pyometra, respectively (14-16). It was found least effective in cases of closed pyometra (24\%), which brought about the use of progesterone antagonists like aglepristone $(15,17)$, which improve efficacy when combined with prostaglandins, above all, in order to carry out therapies in bitches of high economic value and where surgery is not an option (18).

The principal cause of canine pyometra, in $90 \%$ of cases, is Escherichia coli in $90 \%$ of cases $(2,6,19)$, which penetrates the uterus during estrus $(5,19,20)$. For this reason treatment should always be accompanied by antibiotics or antimicrobials, especially with a spectrum

\section{INTRODUCCIÓN}

El piómetra es una patología uterina de origen bacteriano favorecida por acción de la progesterona durante ciclos de celos sucesivos, también por una terapia exógena con estrógenos y/o progestágenos (1). Se reporta principalmente en hembras mayores de 6 años $(2,3)$.

Es un proceso patológico que suele iniciar con hiperplasia endometrial quística (HEQ), y que permite la proliferación de bacterias provenientes de la vagina, llevando a la acumulación de material purulento al interior del útero (3-5). Es considerada como una de las alteraciones patológicas más frecuentes en reproducción de caninos $(4,6)$. Se inicia en la fase estral del ciclo reproductivo, por cambios morfológicos inducidos por la progesterona (P4) y los estrógenos (E2), con una respuesta anormal del útero en la fase lútea, que unido a la acción bacteriana ocasiona el piómetra $(5,7)$. Se distinguen dos formas clínicas: piómetra de cuello cerrado, cuyos signos son más severos y el piómetra de cuello abierto. Algunos de los signos comunes son: vómito, polidipsia, poliuria y anorexia $(2,3,5)$.

El tratamiento del piómetra debe ser urgente y agresivo, con la extracción del contenido, que por lo general es quirúrgico en el $80 \%$ de los casos (810). Sin embargo, el tratamiento farmacológico también es posible (11-13). La efectividad en el uso de prostaglandina natural $\mathrm{F} 2 \alpha$ se ha descrito en el $55 \%$ de casos de piómetra abierto y $24 \%$ en piómetra cerrado, respectivamente (14-16). La menor efectividad encontrada en los casos de piómetra cerrado (24\%), llevó al uso de antagonistas de la progesterona como aglepristone $(15,17)$, los cuales mejoraron la efectividad al unirse con las prostaglandinas, sobre todo para realizar terapias en perras de alto valor económico y donde la cirugía no es una opción (18).

El principal agente causante del piómetra canino es Escherichia coli en el $90 \%$ de los casos $(2,6,19)$, el cual penetra al útero durante el estro $(5,19,20)$. Por ello el tratamiento debe ir siempre 
against Gram-negative microorganisms such as gentamicin, amikacin, enrofloxacin, ciprofloxacin, among others (19).

Females treated jointly with progesterone antagonists and natural or synthetic prostaglandins $\mathrm{F} 2 \alpha$ were $75 \%$ of the time cured $(11,15,17)$, while patients that only received prostaglandins only reached $60 \%$ (13). This is due to the fact that the canines presented less uterine response to the use of prostaglandins (11, 160); other treatments have been mentioned as having similar results $(8,12,18)$. Among these Corrada et al (14) describe the effectiveness of using dopamine agonists (Cabergoline) in treating canine pyometra.

Various studies demonstrated the cure of pyometra with only a single use of $10 \mathrm{mg} / \mathrm{kg}$ of antiprogestin aglepristone subcutaneously on days 1,2 and 8 of the diestrus, combined with cloprostenol, which induces the opening of the cervix and the resulting drainage of the uterus (13-15). Other protocols with an efficacy of $95 \%$ are: $10 \mathrm{mg} / \mathrm{kg}$ of aglepristone subcutaneously on days $1,3,8$, and 15 of the diagnosis, combined with cloprostenol $1 \mu \mathrm{g} / \mathrm{kg}$ subcutaneously on days 3 and 8 , or both combined on days 3, $5,8,10,12$ and $15(13,18)$. Only Molina (18) describes using aglepristone as a singular therapy in a report on the case of a French Bull Dog with pyometra. However, the efficacy of aglepristone as a singular medicine for this treatment has not been determined in a comparative study.

The objective of the present study was to value the efficacy of the antiprogestin aglepristone with and without cloprostenol in treating pyometra in female canines.

\section{MATERIAL AND METHODS}

Study location. Veterinary Clinic of Antioquia, Medellín Colombia, from 2011 to 2013.

Animals. 10 female French Bulldogs, between 3-8 years of age, diagnosed with closed pyometra.

All animals used were of high breeding value because of which their owners sought alternative therapy to conventional ovariohysterectomy. All bitches had closed pyometra, with clinical signs of polydipsia, polyuria, vomiting, lack of energy and anorexia; as well as their last heat being 45-60 days prior.

Experimental design and treatments. The females were randomly assigned to one of the two treatment groups, one with a $10 \mathrm{mg} / \mathrm{kg}$ dose acompañado de antibióticos o antimicrobianos, en especial con espectro contra microorganismos Gram negativos como lo son la gentamicina, amikacina, enrofloxacina, ciprofloxacina, entre otros (19).

Las hembras tratadas conjuntamente con antagonistas de la progesterona y prostaglandinas F $2 \alpha$ natural o sintéticas curan en un $75 \%$ $(11,15,17)$, mientras que pacientes que sólo reciben prostaglandinas lo hacen hasta en el $60 \%$ (13). Lo cual se debe a que los caninos presentan menor respuesta uterina al sólo uso de prostaglandina $(11,16)$; otros tratamientos se han descrito con resultados similares $(8,12,18)$. Dentro de los cuales Corrada et al (14), describen la efectividad del uso de agonistas de la dopamina (Cabergolina) en el tratamiento del piómetra canino.

Varios estudios demostraron resolución del piómetra con el sólo uso del antiprogestágeno aglepristone a dosis de $10 \mathrm{mg} / \mathrm{kg}$ subcutáneo, los días 1,2 y 8 del diestro, unido a cloprostenol, el cual induce la apertura del cérvix y el consiguiente drenaje uterino (13-15). Otros protocolos con eficacia del 95\%, son: aglepristone $10 \mathrm{mg} / \mathrm{kg}$ subcutáneo a los días $1,3,8$, y 15 del diagnóstico, combinado con cloprostenol $1 \mu \mathrm{g} / \mathrm{kg}$ subcutáneo los días 3 y 8 , o bien ambos combinados los días 3, 5, 810,12 y $15(13,18)$. Pero sólo Molina (18) describe el uso de aglepristone como única terapia en un reporte de un caso de una Bulldog francés con piómetra. Pero no se ha determinado la efectividad del aglepristone como único medicamento para este tratamiento, en un estudio comparativo.

El objetivo del presente estudio fue valorar la eficacia del antiprogestágeno aglepristone con y sin el cloprostenol en el tratamiento del piómetra en hembras caninas.

\section{MATERIALES Y MÉTODOS}

Sitio de estudio. Clínica Veterinaria de Antioquia, Medellín Colombia, entre los años 2011 a 2013.

Animales. 10 hembras caninas de la raza Bulldog Francés, entre 3-8 años de edad, con diagnóstico de piómetra cerrado.

Todas las hembras utilizadas eran animales de alto valor reproductor por lo que el propietario buscaba otra alternativa terapéutica diferente a la ovariohisterectomía convencional. Todas las perras presentaron piómetra cerrado, con los signos clínicos de polidipsia, poliuria, vómito, decaimiento y anorexia; Así como historia de celo hace 45-60 días. 
of aglepristone administered subcutaneously on days $1,2,8,14$ and 28 ; the other with a $10 \mathrm{mg} / \mathrm{kg}$ dose of aglepristone administered subcutaneously on days $1,3,8$ and 15 , and $1 \mu \mathrm{g} / \mathrm{kg}$ of cloprostenol given subcutaneously on days 3 and 8 . Both groups received a complementary therapy with $5 \mathrm{mg} / \mathrm{kg}$ of enrofloxacin given orally every 12 hours for 28 days.

The pyometra diagnosis in all patients was made by means of a clinical exam, blood profile, as cited later on, and confirmation by echography.

Evaluation of the bitches. The hematological evaluation was carried out starting with blood samples from the jugular vein, gathered in tubes with EDTA on days 1 and 28 of the diagnostic. The samples were processed on Abacus junior vet $^{\circledR}$ (Diatron Ltda, Austria) equipment according to the following parameters: hematocrit (HCT), hemoglobin (HGB), mean corpuscular hemoglobin concentration (MCHC), erythrocytes, leukocytes, neutrophils $(N)$, eosinophils $(E)$, lymphocytes $(L)$, lemniscus (B), monocytes (M), platelets (PL) and plasma proteins.

The evaluation of uterine contents was made with an abdominal echography using a Midray DP $3300 \mathrm{~B} / \mathrm{N}^{\circledR}$ system every 8 days, during the 28 days of treatment. In addition, the followup included: time until the next proestrus (by vaginal smear and progesterone measurements above $8 \mathrm{mg} / \mathrm{ml}$ ), the days of expulsion uterine content and the time of clinical recuperation of each patient, measured by the absence of clinical signs; among which were evaluated: absence of vomiting, absences of abdominal pain through palpation, measured according to the Universidad de Melbourne (UMPS) pain scale, return of appetite and normal activity. The evaluation of the patient was ambulatory until resolving the symptoms.

The females were paired and naturally mated on days 11,14 and 16 from the initial day of proestrus. For this study only the presence or absence of gestation was evaluated by echography 23 days after copulation; no further monitoring was carried out on the non-pregnant females.

Statistical analysis. The variables were subject to ANOVA, with Tukey HSD and $\mathrm{Chi}^{2}$ tests for qualitative variables and with a non-parametric test (Mann Whitney test).

Informed consent. All owners of the bitches signed a consent form, accepting the administration of medication as an alternative to ovariohysterectomy. The investigation was approved by the University Corporation of Sabanet (Unisabaneta) ethics
Diseño experimental y tratamientos. Las hembras fueron asignadas de manera aleatoria a uno de los dos grupos de tratamiento, un grupo con aglepristone a dosis de $10 \mathrm{mg} / \mathrm{kg}$ subcutáneo los días 1 , 2, 8, 14 y 28; el otro con aglepristone a dosis de $10 \mathrm{mg} / \mathrm{kg}$ subcutáneo los días 1,3 , 8 y 15 , más cloprostenol $1 \mu \mathrm{g} / \mathrm{kg}$ subcutáneo el día 3 y 8 . Ambos grupos recibieron una terapia complementaria con enrofloxacino $5 \mathrm{mg} / \mathrm{kg}$ vía oral cada 12 horas por 28 días.

El diagnóstico de piómetra en todas las pacientes fue realizado mediante el examen clínico, perfil sanguíneo como se cita a continuación y confirmados por ecografía.

Evaluación de las perras. La evaluación hematológica fue realizada a partir de muestras de sangre de la vena yugular, recolectada en tubos con EDTA los días 1 y 28 del diagnóstico. Las muestras fueron procesadas en equipo Abacus junior vet ${ }^{\circledR}$ (Diatron Ltda, Austria) para los siguientes parámetros: hematocrito (Hto), hemoglobina $(\mathrm{Hg})$, volumen corpuscular medio (VCM), hemoglobina corpuscular media ( $\mathrm{HgCM})$, concentración de hemoglobina corpuscular media $(\mathrm{CHgCM})$, eritrocitos, leucocitos, neutrófilos $(N)$, eosinófilos $(E)$, linfocitos $(L)$, bandas $(B)$, monocitos $(M)$, plaquetas $(P L)$ y proteínas plasmáticas.

La evaluación del contenido uterino, se realizó mediante ecografía abdominal con un equipo Midray DP $3300 \mathrm{~B} / \mathrm{N}^{\circledR}$ cada 8 días, durante los 28 días de tratamiento. Además, el seguimiento incluyó: tiempo de retorno al proestro (por citología vaginal y mediciones de progesterona por encima de $8 \mathrm{mg} / \mathrm{ml}$ ), los días de expulsión del contenido uterino y el tiempo de recuperación clínica de cada paciente, medido por la ausencia de signos clínicos; dentro de los cuales fueron evaluados: ausencia de vómito, ausencia de dolor abdominal por palpación, medido según escala de dolor Universidad de Melbourne (UMPS), retorno del apetito y retorno de actividad normal. La evaluación del paciente fue realizada de manera ambulatoria hasta resolver los signos.

Las hembras fueron apareadas con monta natural los días 11,14 y 16 de iniciado el proestro. Para este estudio sólo fue evaluada la presencia o ausencia de la gestación por ecografía a los 23 días de la cópula; a las hembras no gestantes no se les realizó seguimiento posterior.

Análisis estadístico. Las variables fueron sometidos a ANOVA, con el test de HSD Tukey y $\mathrm{Chi}^{2}$ para las variables cualitativas y con test no paramétrico (Mann Whitney test). 
committee, by means of resolution 001 on October 2013.

\section{RESULTS}

Ten female French Bulldogs were evaluated, of which there was not found a significant difference between groups and protocols $(p \geq 0.05)$. In the aglepristone group the average age was $4.2 \pm 1.92$ years and in the combined aglepristone and cloprostenol group $3.2 \pm 1.30$ years.

In the hemogram evaluation during the two periods, day 0 and 28 , no variation in the red line was observed, neither before nor after the treatment (Table 1), there was no significant difference between inter or intra treatments $(p \geq 0.05)$.

Table1. Average values ( $\pm D . S$ ) of some hemogram variables during the evaluation of the pyometra treatment.

\begin{tabular}{lcccccc}
\hline \multirow{1}{*}{ Treatment } & \multicolumn{2}{c}{$\begin{array}{c}\text { Hematocrit } \\
(\%)\end{array}$} & $\begin{array}{c}\text { Hemoglobin } \\
(\mathbf{g} / \mathbf{d l})\end{array}$ & $\begin{array}{c}\text { Red blood cells } \\
\left(\mathbf{1} \times \mathbf{1 0}^{6} / \mathbf{m l}\right)\end{array}$ \\
& Day 0 & Day 28 & Day 0 & Day 28 & Day 0 & Day 28 \\
\hline \multirow{2}{*}{ Aglepristone Group } & 43.2 & 42.6 & 14.4 & 14.2 & 4.0 & 4.4 \\
& $\pm 5.9^{\mathrm{a}}$ & $\pm 3.8^{\mathrm{a}}$ & $\pm 1.9^{\mathrm{a}}$ & $\pm 1.3^{\mathrm{a}}$ & $\pm 0.4^{\mathrm{a}}$ & $\pm 0.3^{\mathrm{a}}$ \\
Aglepristone & 43.4 & 42.2 & 14.5 & 14.0 & 4.5 & 4.6 \\
cloprostenol Group & $\pm 3.4^{\mathrm{a}}$ & $\pm 2.6^{\mathrm{a}}$ & $\pm 1.2^{\mathrm{a}}$ & $\pm 0.9^{\mathrm{a}}$ & $\pm 0.5^{\mathrm{a}}$ & $\pm 0.5^{\mathrm{a}}$ \\
\hline
\end{tabular}

a None of the variables had significant difference $(p \geq 0.05)$.

In the leukogram there was no statistical difference found between aglepristone and aglepristone in addition to cloprostenol $(p \geq 0.05)$, but there a difference was found between the values on day 0 and 28 . For this reason the information from both treatment groups was analyzed together for each variable and time measurement. In this analysis it was found that all variables analyzed by the leukogram showed lesser post treatment values (Table 2). These results show that both treatments decreased the number of white blood cells, neutrophils and lemniscus', compared with the values before treatment $(p \leq 0.05)$.

There was no significant difference $(p \geq 0.05)$ between both protocols in regards to days of recuperation for the following clinical variables: days until the next proestrus (138 days), days until a normal echography (15 days), days until absence of vomiting (6.2 days) and days until an absence of polydipsia/polyuria (5.6 days) (Table 3 ). However, variables such as the days of absence of abdominal pain, days of vaginal secretion, days until normal appetite and days of normal activity, showed statistical
Consentimiento informado. Todos los propietarios de las hembras firmaron un consentimiento informado, aceptando la realización de la medicación como alternativa a la ovariohisterectomía. La investigación fue aprobada por el comité de ética de la Corporación Universitaria de Sabaneta (Unisabaneta), mediante resolución número 001 de octubre 2013.

\section{RESULTADOS}

Diez hembras Bulldog Francés fueron evaluadas, de las cuales para el grupo de aglepristone la edad promedio fue $4.2 \pm 1.92$ años y de $3.2 \pm 1.30$ años para el aglepristone más cloprostenol, no se encontró diferencia significativa entre grupos $y$ protocolos $(p \geq 0.05)$.

En la evaluación del hemograma durante los dos tiempos día 0 y 28 , no se observó variación en la línea roja, ni antes ni después del tratamiento (Tabla 1), no hubo diferencia significativa inter o intra tratamientos $(p \geq 0.05)$.

En el leucograma no se encontró diferencia estadística entre aglepristone y aglepristone más cloprostenol $(p \geq 0.05)$, pero sí encontró una diferencia entre los valores del día 0 y 28. Por esto se analizaron en conjunto los datos de los dos grupos de tratamiento por cada variable y momento de medición. En este análisis se encontró que todas las variables analizadas del leucograma mostraron valores menores postratamiento (Tabla 2). Estos resultados muestran que ambos tratamientos disminuyeron los valores de los glóbulos blancos, neutrófilos y bandas, comparado con los valores antes del tratamiento $(p \leq 0.05)$.

No hubo diferencias significativas $(p \geq 0.05)$ entre ambos protocolos para los días de recuperación de las siguientes variables clínicas: días de retorno al proestro (138 días), días para ecografía aparentemente normal (15 días), días para ausencia de vómito (6.2 días) y días para ausencia de polidipsia/poliuria (5.6 días) (Tabla 3). Pero las variables días de ausencia de dolor abdominal, días de secreción vaginal, días a apetito normal y días de actividad normal, mostraron diferencia estadística $(p \leq 0.05)$, siendo menor para el grupo de Aglepristone cloprostenol (Tabla 3).

Las 5 hembras de cada protocolo se aparearon en el primer celo. De ellas, el $40 \%$ (3 de 5) del grupo de aglepristone quedo gestante, con diagnóstico ecográfico a los 23 días pos monta, mientras que sólo el $20 \%$ ( 1 de 5 ) del grupo aglepristone y cloprostenol quedo preñada. Todas las hembras 
Table 2. Average values ( $\pm D S$ ) of the leukogram for French Bulldog bitches with pyometra and treated with aglepristone alone or combined with cloprostenol.

\begin{tabular}{|c|c|c|c|c|c|c|}
\hline \multirow[t]{2}{*}{ Treatment } & \multicolumn{2}{|c|}{$\begin{array}{c}\text { White blood } \\
\text { cells } \\
\left(1 \times 10^{3} / \mathrm{ml}\right)\end{array}$} & \multicolumn{2}{|c|}{$\begin{array}{l}\text { Neutrophils } \\
\left(1 \times 10^{3} / \mathrm{ml}\right)\end{array}$} & \multicolumn{2}{|c|}{$\begin{array}{l}\text { Lemniscus' } \\
\left(1 \times 10^{3} / \mathrm{ml}^{\prime}\right)\end{array}$} \\
\hline & Day 0 & Day 28 & Day 0 & Day 28 & Day 0 & Day 28 \\
\hline Aglepristone Group & $\begin{array}{l}20.7 \\
\pm 0.9^{a}\end{array}$ & $\begin{array}{l}14.6 \\
\pm 1.2^{\mathrm{b}}\end{array}$ & $\begin{array}{l}16.1 \\
\pm 0.6^{a}\end{array}$ & $\begin{array}{l}9.5 \\
\pm 0.6^{\mathrm{b}}\end{array}$ & $\begin{array}{l}0.7 \\
\pm 0.2^{\mathrm{a}}\end{array}$ & $\begin{array}{l}0.2 \\
\pm 0.2^{\mathrm{b}}\end{array}$ \\
\hline $\begin{array}{l}\text { A g I e p riston e } \\
\text { cloprostenol Group }\end{array}$ & $\begin{array}{l}20.1 \\
\pm 2.3^{\text {a }}\end{array}$ & $\begin{array}{l}13.7 \\
\pm 0.9^{\mathrm{b}}\end{array}$ & $\begin{array}{l}14.7 \\
\pm 1.2^{\mathrm{a}}\end{array}$ & $\begin{array}{l}8.8 \\
\pm 0.9^{b}\end{array}$ & $\begin{array}{l}0.8 \\
\pm 0.1^{\mathrm{a}}\end{array}$ & $\begin{array}{l}0.2 \\
\pm 0.2^{\mathrm{b}}\end{array}$ \\
\hline
\end{tabular}

$a, b$ The numbers with a different superscript for each row imply significant differences $(p \leq 0.05)$. There was no significant difference between both groups for each variable of the same day.

differences $(p \leq 0.05)$, being less for the combined aglepristone and cloprostenol group (Table 3).

All 5 females in each protocol paired during their first heat. Of them, $40 \%$ (3 out of 5 ) of the aglepristone group became pregnant, with a diagnostic echography on day 23 post mating, while only $20 \%$ ( 1 out of 5 ) of the aglepristone and cloprostenol group were impregnated. All pregnant females carried their pregnancy to full term. The present study did not evaluate the number of puppies or the vitality and malformation of the neonates. None of the bitches showed adverse clinical signs or local effects associated with the treatments.

\section{DISCUSSION}

The presence of the disease does not coincide with population data found by other authors, and there is no particular prevalence according to breed, thus, the French Bulldog was chosen in particular because of its high economic value. The table refers to females greater than four years of age, as mentioned by other authors $(2,3)$, which does not coincide with the present work where the age was 4.2 years for the aglepristone group and 3.2 years for the aglepristone and cloprostenol group, indicating that they were young females, one cannot infer that the French Bulldog as a breed is the explanation, since pyometra has been found in young animals of different breeds (3).

The results indicate that treatments with aglepristone or aglepristone with cloprostenol probably have similar results as regards to the values of the full blood count. It is evident that the increase in the number of white blood cells, neutrophils and lemniscus' are characteristic to canine pyometra, as mentioned by many authors $(15,21)$. However, the aglepristone and the aglepristone with cloprostenol treatments,
Table3. Average values ( $\pm D S$ ) of days until the normalization of the clinical variables during the evaluation of the pyometra treatment.

\begin{tabular}{|c|c|c|c|c|c|c|c|c|}
\hline Treatment & DS & DP & DNE & DAV & DAP & DNA & DNA & DAPP \\
\hline $\begin{array}{l}\text { Aglepristone } \\
\text { Group }\end{array}$ & $\begin{array}{l}10.0 \\
\pm 1.6^{a}\end{array}$ & $\begin{array}{c}139.8 \\
\pm 17.8^{a}\end{array}$ & $\begin{array}{l}16.0 \\
\pm 2.0^{\mathrm{a}}\end{array}$ & $\begin{array}{c}6.8 \\
\pm 1.9^{\text {a }}\end{array}$ & $\begin{array}{l}10.2 \\
\pm 1.5^{a}\end{array}$ & $\begin{array}{c}10.4 \\
\pm 1.1^{\mathrm{a}}\end{array}$ & $\begin{array}{c}7.8 \\
\pm 1.3^{\mathrm{a}}\end{array}$ & $\begin{array}{c}5.6 \\
\pm 1.5^{a}\end{array}$ \\
\hline $\begin{array}{l}\text { Aglepristone } \\
\text { cloprostenol } \\
\text { Group }\end{array}$ & $\begin{array}{c}7.2 \\
\pm 1.3^{b}\end{array}$ & $\begin{array}{c}137.0 \\
\pm 17.7^{a}\end{array}$ & $\begin{array}{l}13.8 \\
\pm 1.5^{a}\end{array}$ & $\begin{array}{c}5.6 \\
\pm 0.5^{\mathrm{a}}\end{array}$ & $\begin{array}{l}7.0 \\
\pm 1.6^{\mathrm{b}}\end{array}$ & $\begin{array}{l}7.0 \\
\pm 1.0^{\mathrm{b}}\end{array}$ & $\begin{array}{l}5.0 \\
\pm 1.0^{\mathrm{b}}\end{array}$ & $\begin{array}{c}5.6 \\
\pm 1.1^{\mathrm{a}}\end{array}$ \\
\hline $\begin{array}{l}\text { S: Days of s } \\
\text { chography; D } \\
\text { bsence of pai } \\
\text { ppetite; DAPP } \\
\text { b The numbers }\end{array}$ & in; & : Days & s to $n$ & f nor & tetro & ת & iy & \\
\hline
\end{tabular}

gestantes presentaron una gestación a término. En el presente estudio, no se evaluó el número de cachorros, vitalidad y malformación de los neonatos. Ninguna de las perras mostró signos clínicos adversos o efectos locales asociados con los tratamientos.

\section{DISCUSIÓN}

La presencia de la enfermedad no coincide con los datos poblacionales encontrados por otros autores, pero no hay prevalencia en particular según la raza, debido a que se escoge una raza en particular Bulldog francés, por tratarse de animales de alto valor económico. La edad descrita por otros autores refiere el cuadro a hembras mayores de 4 años $(2,3)$, lo cual no coincide en el presente trabajo donde las edades estaban en 4.2 para el aglepristone y 3.2 años para aglepristone más cloprostenol respectivamente, lo cual indica que se trataba de hembras jóvenes, no se puede inferir que por tratarse de la raza Bulldog francés esta sea la explicación pues el piómetra se ha descrito en animales jóvenes de diferentes razas (3).

Los resultados indican que probablemente los tratamientos con aglepristone o aglepristone con cloprostenol, tienen resultados similares en cuanto a los valores del hemoleucograma. Es evidente que los valores aumentados de los glóbulos blancos, neutrófilos y bandas son característicos del piómetra canino, como los describen muchos autores $(15,21)$. Pero el tratamiento con aglepristone y aglepristone con cloprostenol, combinados con antimicrobianos, permitieron la recuperación de las variables del leucograma alteradas, lo que concuerda con resultados de otros estudios $(19,21)$, donde la leucocitosis y neutrofilia sede al uso de ambos protocolos, debido a la eliminación del contenido piógeno. Además, el uso de enrofloxacina, demostró ser eficaz, en el control de la infección, 
combined with antimicrobials, allowed the recuperation of the altered leukogram variables, which agrees with the results of other studies $(19,21)$, where the use of both protocols mitigates leukocytosis and neutrophil by eliminating pyogenic material. Moreover, the use of enroflaxacin proved to be effective in the control of the infection, similar to those already mentioned for gentamicin in another study (19).

All bitches in this study presented uterine contents in the ultrasound evaluation, from 15 days on average which coincide with the results of other authors $(13,15,18)$. Also, both treatments showed a similar behavior in regards to days of recuperation of the clinical variables: days of proestrus, days until absence of vomiting and days until absence of polydipsia/polyuria (15, 16). Treatment with a combination of aglepristone and cloprostenol showed an advantage in regards to days of secretion, with an average of 7.2 days compared with 10 days for treatment with only aglepristone. This coincides with other studies where the greater effect of this combination is confirmed (22); none the less, this data differ from the 3 days of secretion reported by those who used at least one protocol of aglepristone with cloprostenol similar to that of this study (17). In vitro studies have demonstrated that the progesterone antagonist induced by aglepristone improves contractile activity of the myometrium induced by prostaglandins (16), which clinically implies assistance in the elimination of pyogenic material in less time, facilitating recuperation.

In this study the lowest average number of days until absence of pain, and days to normal activity and appetite associated with the combined treatment of aglepristone with cloprostenol, is related to the lowest number of days of uterine discharge and improvement of clinical evaluation, which can be related to studies that indicate a higher contractile capacity of the myometrium from the combination of aglepristone with cloprostenol than only aglepristone $(15,18)$. However, the present study did not determine values according to the UMPS scale, it was only used to determine presence or absence of pain and this was observed when values decreased, indicating improvement.

None of the bitches in this study had a recurrence of the disease, at least not in the estrous cycle subsequent to this study, which does not rule out the occurrence of the disease in the rest of the subsequent estrous cycles, because they could not be evaluated in this study. The group of bitches in this study were young, none of which passed 7 years of age, which coincides with previous studies where there was no recurrence similar a los ya descritos para la gentamicina en otro estudio (19).

Todas las perras de este estudio a la evolución ecografica presentaron contenido uterino, a partir del día 15 en promedio y coincide con los resultados de otros autores $(13,15,18)$. Además, ambos tratamientos mostraron un comportamiento similar en los días de recuperación de las variables clínicas días de proestro, días a ausencia de vómito y días a ausencia de polidipsia/poliuria $(15,16)$. En el tratamiento de aglepristone con cloprostenol se observa una ventaja en los días de secreción, con un promedio de 7.2 días comparado con los 10 días del tratamiento con aglepristone sólo y coincide con otros estudios donde se ratifica el mejor efecto de esta combinación (22); sin embargo, estos datos difieren de los 3 días de secreción reportados por quienes utilizaron al menos un protocolo de aglepristone y cloprostenol similar al de este estudio (17). Estudios in vitro han demostrado que el antagonismo de la progesterona inducido por el aglepristone mejora la actividad contráctil del miométrio inducido por las prostaglandinas (16), lo que clínicamente implica que se favorece la eliminación del contenido piógeno en menor tiempo, favoreciendo la recuperación.

En este estudio el menor promedio de días a ausencia de dolor, días a actividad normal y días a apetito normal asociadas a la adición del tratamiento de aglepristone con cloprostenol, está relacionado con el menor número de días de descargas uterinas y la mejora de la evolución clínica puede estar relacionada con los estudios que indican una mayor capacidad contráctil del miometrio de aglepristone con cloprostenol, que aglepristone sólo $(15,18)$. Pero el presente estudio no determina los valores según la escala UMPS, sólo se usó para determinar presencia o ausencia de dolor y esto se dió cuando los valores disminuyeron como indicativo de mejoría.

Ninguna de las perras de este estudio presentaron recidiva de la enfermedad al menos en un ciclo estral posterior a este estudio, lo que no descarta la presencia de esta enfermedad en los demás ciclos posteriores, que para este estudio no pudieron ser evaluado. El grupo de perras de este estudio fue joven pues ningún animal superó los 7 años de edad y coincide con estudios previos en donde no hubo reincidencia de la enfermedad en el siguiente ciclo en animales menores de 5 años y de donde se concluye que se obtienen mejores resultados en preservar la fertilidad de la hembras tratadas en animales jóvenes (23). 
of the disease in the following cycle in animals less than 5 years of age and from which it is concluded that better results in preserving female fertility is obtained in young animals (23).

In the present study no side effects associated with the use of prostaglandins was found, such as: vomiting, sialorrhea, nausea, diarrhea, hypotension, tachycardia, shock and death, as is described in handling doses of $2.5 \mu \mathrm{g} / \mathrm{kg}(16)$. Similar circumstances were reported by other canine studies (13). This could be due to the use of low doses of cloprostenol in this study. Further, neither the aglepristone treatment reported side effects, which compares with the results of previous studies (24).

These results should continue to be analyzed, even though there is clinical evidence that the combination of aglepristone with cloprostenol can generate better results, as are describes by Gobello et al (13), Fieni (15) and Jena et al (21), in curing patients. The present study demonstrates that only using aglepristone is sufficient for guaranteeing the recuperation of the patient, similar to what is described by Molina (18). The analysis should be guided toward not only guaranteeing future fertility, but also to avoid side effects and risk to the life of the female, through the use of synthetic prostaglandin $(16,25)$.

In addition, to dispute the concept that pyometra is a reproductive disease in female canines that requires surgical treatment $(3,5,26)$, due to the pathogenicity of its etiologic agent and its death rate $(2,3,21)$, it is known that procedures like the ovariohysterectomy, which eliminates possible recurrence (11), leave breeding females without the possibility of progeny. None the less, surgical treatments have their limits when the surgical risk increases or the owner refuses $\mathrm{OVH}$ because they are patients of high breeding value, in which the possibility of sterilization is considered expensive (20).

It is at this point where progesterone antagonists play an important role, especially the use of aglepristone, which due to its medical advantage in facilitating the contractibility of the myometrium, permits the elimination of pyogenic material $(12,15,26)$, relaxing the uterine neck, due to its competitive effect against progesterone (17). Compared to the use of prostaglandin, which smooth the corpus luteum (16), giving the doctor a new possibility of high effectiveness in treating both open and closed pyometra. Reports are found where the use of aglepristone as the sole medication achieved beneficial curative effects greater than $75 \%$ (11); similar to those
En el presente estudio no se encontraron efectos colaterales asociados con el uso de prostaglandinas, como: vómito, sialorrea, nauseas, diarrea, hipotensión, taquicardia, choque y muerte, como se describen con el manejo de dosis de $2.5 \mu \mathrm{g} / \mathrm{kg}$ (16). Similares circunstancias fueron de reportadas por otros estudios en caninos (13), esto se puede deber al uso de bajas dosis de cloprostenol utilizadas en este estudio, además, el tratamiento con aglepristone tampoco reportó efectos colaterales comparado con los resultados de estudios previos (24).

Estos resultados deben seguir siendo analizados, pues aunque hay evidencia clínica de que la combinación aglepristone con cloprostenol, puede generar mejores resultados, como los descritos por Gobello et al (13), Fieni (15) y Jena et al (21), en la curación del paciente. El presente estudio demostró que sólo el uso de Aglepristone es suficiente para garantizar la recuperación del paciente, similar a los descrito por Molina (18). El análisis debe ser encaminado no sólo a garantizar la fertilidad futura, sino de evitar los efectos colaterales y el riesgo para la supervivencia de la hembra, tras el uso de la prostaglandina sintética $(16,25)$.

Además, controvertir el concepto de que el piómetra como enfermedad reproductiva de la hembra canina, es una enfermedad de tratamiento quirúrgico $(3,5,26)$, debido a la patogenicidad de su agente etiológico y su mortalidad $(2,3,21)$, pues se sabe que los procedimientos como la ovario histerectomía, que elimina la posible recurrencia (11). Pero dejan a las hembras reproductoras sin la posibilidad de progenie. Sin embargo, los tratamientos quirúrgicos tienen sus límites donde el riesgo de cirugía se incrementa o existe el caso donde el dueño reproche la OVH porque son pacientes de alto costo reproductivo, en el que la posibilidad de esterilizaciones se considera onerosa (20).

Es en este punto donde los antagonistas de la progesterona juegan un papel importante, en especial el uso del aglepristone, que debido a su ventaja farmacológica al facilitar la contractibilidad del miometrio, permite la eliminación del contendido piógeno $(12,15,26)$, relajando el cuello uterino, debido a su efecto competitivo frente a la progesterona (17). Comparado con el uso de prostaglandina, que lisa el cuerpo lúteo (16), este permite al clínico una nueva posibilidad de alta efectividad en el tratamiento del piómetra tanto abierto como cerrado, se encontró reportes donde sólo el uso del aglepristone como único medicamento logró efectos benéficos curativos por encima del 75\% (11); similar a lo descrito por Molina (18), donde encontró una recuperación total del 
mentioned by Molina (18), where the patient was completely cured, while the complementary use of aglepristone with prostaglandin F2 $\alpha$ was $90 \%$ effective $(7,15)$. Achieving recuperation within the first 3 weeks after initiating the treatment; with a short-term successful healing rate of $92.3 \%$, the use of aglepristone as the only tool is certainly justifiable.

The therapeutic response to the use of aglepristone was excellent with no side effects. In addition, the presence of two treatment protocols allows the veterinarian the opportunity to manage medication depending on the severity of the case.

In conclusion, treatments with aglepristone and a combination of aglepristone with cloprostenol, along with enrofloxacin, permit the recuperation of the animal with pyometra in the variables of the full blood count on day 28; nonetheless, the combination of aglepristone with cloprostenol obtained better results in the recuperation of the treated females.

\section{Acknowledgements}

To the Veterinary Clinic of Antioquia for allowing us to use their facilities and patients for the present study. To the Corporación Universidad de Sabaneta and to Caequinos for providing the technical personnel for the present study. paciente. Mientras que el uso complementario de aglepristone con prostaglandina $F 2 \alpha$, alcanzó el $90 \%$ de efectividad $(7,15)$. Logrando la recuperación dentro de las 3 primeras semanas después de iniciado el tratamiento; con una tasa de curación exitosa de corto plazo de $92.3 \%$, el uso de aglepristone como única herramienta es ciertamente justificable.

La respuesta terapéutica al uso de aglepristone fue excelente con efectos secundarios nulos, además, la presencia de dos protocolos de tratamiento permiten al médico veterinario tratante la oportunidad de manejar la medicación dependiendo de la severidad del cuadro.

En conclusión los tratamientos con aglepristone y aglepristone con cloprostenol, más combinación con enrofloxacina, permitieron la recuperación de los animales con piómetra en las variables de hemoleucograma al día 28 de evolución; sin embargo, la combinación aglepristone con cloprostenol obtuvo mejores resultados en la recuperación de las hembras tratadas.

\section{Agradecimientos}

A la colaboración de la Clínica Veterinaria de Antioquia, por facilitar las instalaciones y pacientes para la presente investigación. A la Corporación Universitaria de Sabaneta y a Caequinos por proveer el personal técnico para el presente estudio.

\section{REFERENCIAS}

1. Greene C. Infectious diseases of the dog and cat. Missouri: Elsevier; 2012.

2. Baithalu RK, Maharana BR, Mishra C, Sarangi L, Samal L. Canine Pyometra. Vet World 2010; 3(7):340-2.

3. Smith FO. Canine Pyometra. Theriogenology 2006; 66:610-2.

4. Verstegen J, Dhaliwal G, Verstegen-Onclin K. Mucometra, cystic endometrial hyperplasia, and pyometra in the bitch: advances in treatment and assessment of future reproductive success. Theriogenology 2008; 70(3):364-74.

5. Silva-Molano RF, Loaiza-Echeverri AM. Pyometrain small animals. Vet Zootec 2007; 1(2):71-86.
6. Kempisty B, Bukowska D, Wozna M, Piotrowska $\mathrm{H}$, Jackowaska M, Zuraw A, et al. Endometritis and pyometra in bitches: a review. Vet Med 2013; 58(6):289-97.

7. Chen YMM, Lee CS, Wright PJ. The roles of progestagen and uterine irritant in the maintenance of cystic endometrial hyperplasia in the canine uterus. Theriogenology 2006; 66(6-7): 1537-44.

8. Hiremath $S$, Sunilchandra U. Non surgical and non hormonal treatment of open pyometra in a bitch under field conditions - A case report. Intas Polivet 2004; 5(11):329-30.

9. Fossum TW. Cirugía en pequeños animales. Barcelona: Elsevier; 2009. 
10. Nak D, Nak $Y$, Tuna B. Follow-up examinations after medical treatment of pyometra in cats with the progesterone-antagonist aglepristone. J Feline Med Surg 2009; 11(6):499-502.

11. Uçmak M, Çagatay T. Comparison of different methods on the medical treatment of cystic endometrial hyperplasia - pyometra complex in bitches. Bull Vet Inst Pulawy 2008; 52(1):2314.

12. Jena B, Rao KS, Reddy KCS, Raghavan KBP. Comparative efficacy of various therapeutic protocols in the treatment of pyometra in bitches. Vet Med 2013; 58(5):271-6.

13. Gobello C, Klima, Lilia, Rodríguez R, Corrada Y, Castexa G. A study of two protocols combining aglepristone and cloprostenol to treat open cervix pyometra in the bitch. Theriogenology 2003; 60:901-8.

14. Corrada $Y$, Arias D, Rodríguez R, Tortora M, Gobello $C$. Combination dopamine agonist and prostaglandin agonist treatment of cystic endometrial hyperplasia-pyometra complex in the bitch. Theriogenology 2006; 66(6):1557-9.

15. Fieni F. Clinical evaluation of the use of aglepristone, with or without cloprostenol, to treat cystic endometrial hyperplasia pyometra complex in bitches. Theriogenology 2006; 66(1):1550-6.

16. Romagnoli SE, Camillo F, Novellini S, Johnston SD, Cela M. Luteolytic effects of prostaglandin F2alpha on day 8 to 19 corpora lutea in the bitch. Theriogenol. 2006;45(1):397-403.

17. Polisca, A, Scottia, L, Orlandia, R, Brecchiab, G, Maranesib, M, Zeranic, $M$, et al. Aglepristone (RU534) administration to non-pregnant bitches in the mid-luteal phase induces early luteal regression. Theriogenology 2010; 74:672-81.

18. Molina VM. Aglepristone como tratamiento del piometra canino. Journal of Agriculture and Animal Sciences 2012; 1(2):86-93.
19. Bassessar $V$, Verma $Y$, Swamy M. Antibiogram of bacterial species isolated from canine pyometra. Vet Word 2013; 6(8):546-9.

20. Trasch K, Wehrend A, Bostedt H. Follow-up examinations of bitches after conservative treatment of pyometra with the antigestagen aglepristone. J Vet Med Physiol Pathol Clin Med 2003; 50(7):375-9.

21. Jena B, Sadasiva Rao K, Reddy KCS, Raghavan KBP. Physiological and haematological parameters of bitches affected with pyometra. Vet Word 2013; 6(7):409-12.

22. Gogny A, Destrumelle, S, Mallem, Y., Thorin, C, Desfontis, J-C., Gogny, $M$, et al. In vitro comparison of myometrial contractility induced by aglepristone-oxytocin and aglepristonePGF2alpha combinations at different stages of the estrus cycle in the bitch. Theriogenology 2010; 74:1531-8.

23. Jurka P, Max, A, Hawry'nski,K, Snochowski, M. Age-Related Pregnancy Results and Further Examination of Bitches after Aglepristone Treatment of Pyometra. Reprod Dom Anim 2010; 45:525-9.

24. Nak $D$, Nak $Y$, Tuna B. Follow-up examinations after medical treatment of pyometra in cats with the progesterone-antagonist aglepristone. J Feline Med Surg 2009; 11:499-502.

25. Poci Palumbo MI, da Conceição LC, de Araújo Machado LH, Gomes Lourenço ML, Almeida Moreira S, Legatti E, et al. Toxic acute hepatitis associated to the administration of prostaglandin in a dog. Ciênc Rural 2011; 41(9):1578-81.

26. Lika E, Raptil D, Turmalaj L, Gjino P, Robaj A. Medical and Surgical Treatment of Pyometra in Dogs. Maced J Anim Sci 2011; 1(2):391-394. 